\title{
THE COMMUNICATIVE TURN IN GERMAN SOCIOLOGY OF KNOWLEDGE
}

\author{
HUBERT KNOBLAUCH ${ }^{1}$ \\ ${ }^{1}$ Technical University of Berlin, Department of Sociology, Fraunhoferstraße 33-36, Room FH 915, \\ 10587 Berlin, Germany. ORCID: 0000-0002-9461-3160, Email: hubert.knoblauch@tu-berlin.de
}

ABSTRACT: In this paper, I want to start with a short sketch on the development of the German sociology of knowledge which has been quite successful in the last decade. Thus success is very much due to its orientation to the "Social Construction of Reality". Its reception led first to research on language and then to a turn from language to communication which led into what came to be called communicative constructivism. This turn took very much an empirical form, so that we shall sketch the programme implicit in the empirical movement leading to communicative constructivism. Before we address the general sociological background for this movement, i.e. communication society and refiguration, we shall outline its major theoretical features which distinguish communicative constructivism from its predecessor, social constructivism. KEYWORDS: social theory, social constructivism, communicative constructivism, sociology of knowledge, refiguration

\section{INTRODUCTION}

The Sociology of Knowledge can be traced back to many origins. Even within sociology, we find many authors who have stressed the social role of knowledge, starting from Comte to Pareto and, of course, Durkheim. The very notion 'sociology of knowledge" however has been decisively coined almost simultaneously by Max Scheler and Karl Mannheim in den early 1920. Particularly Mannheim's writing caused a lively debate across academic disciplines about the relativity of knowledge, so that the sociology of knowledge became a topic in international sociology. The Third Reich and the Second World War however did mean a rupture to this new movement. Despite the efforts of such scholars as Werner Stark or Georges Gurvitch, the sociology of knowledge seemed to move into the background of academic and even sociological inter- 
est. It was only in the 1960s when it was re-animated in a book by the young Austrian-American sociologists Peter L. Berger and Thomas Luckmann (1966). Their "Social Construction of Reality was subtitled "A Treatise in the Sociology of Knowledge”. And in fact they drew strongly on the theories of Alfred Schutz (1967) who had attempted to refound the sociology of knowledge on the basis of Husserl's phenomenology. The book became an international academic success story which lasts until today. Its reception in the US however and in the anglosaxon language area in general had been mainly focused on the title "social construction". In fact, it can be said that various academic movements labelled "social constructivism" and even 'constructivism' had been inspired and initiated by this book (Hacking 1999) which turned out to become a classic in sociological theory and social theory (Knoblauch/Wilke 2016). Despite its success, anglosaxon approaches to the sociology of knowledge quite frequently ig nored the book as well as the approaches inspired by it. Thus, John Law's book on the "new sociology of knowledge" from 1987 only in bypassing mentions the outstanding analysis of Berger and Luckmann will not be discussed in his paper without any further reason. The same holds for Ann Swidler's and Jorge Adritis “The New Sociology of Knowledge" from 1994, or, MacCarthy's Knowledge as Culture, the new sociology of knowledge from 1998, the last monograph on the sociology of knowledge in English. In France, the reception of the book suffered from the fact that it had been translated only in the late 1980s.

While the anglosaxon reception of the book as part of the sociology of knowledge almost failed, it had massive effects in the German-speaking countries. Very much linked to the return of Luckmann to Germany in the late 1960s, an English/German journal started to be published entitled "International Yearbook for Sociology of Knowledge and Religion”, edited by Günter Dux and Thomas Luckmann which has been published until 1978. ${ }^{1}$ In the late 1990s, a research network on the "sociology of knowledge" became established in the German Sociological Association which has been blooming in the German speaking countries so much that it constitutes nowadays one of the largest networks with a many subgroups, a biannual conference and a number of books series in German as well as in English.

While the success of the Sociology of Knowledge in Germany may appear striking, it is related to the success of its empirical research program which is quite exceptional, too. Topics known from the international debate, such as scientific knowledge, expert knowledge, or knowledge society have been taken up in the German speaking sociology of knowledge, it is characterized by a peculiar focus on communication. The turn to communication will therefore also be in the focus of this article. This is not to claim that all sociology of knowledge in Germany has turned to communication. But the turn to communication, is, as I want to argue, one of the most peculiar, original and innovative contributions of the sociology of knowledge in Germany.

In fact, German sociology lived to see two other spectacular turns towards communication already in the 1980s: In 1981 Habermas published his "Theory of Commu-

\footnotetext{
${ }^{1}$ The role of the sociology of knowledge to religion had been indicated already by Berger and Luckmann
} in an essay anticipating the "Social Construction of Reality" in 1963. nicative Action" in which he founded critical social theory on communicative action, and in 1984 Luhmann reinvented himself by founding the "autopoietic" theory of social systems on the basic process of communication. Yet, while these two "communicative turns' had been performed in social theory only, German sociology of knowledge turn to communication took a decidedly empirical turn. Drawing mainly on qualitative data, these studies made contributed importantly to the foundation, growth and elaboration of interpretive social research methods. Based on the writings of Schutz, one could say that the sociology has performed the "interpretive turn" well before it was received in anthropology and other disciplines (Knoblauch 2013). The analysis of communicative genres, ethnosemantics, hermeneutic sociology of knowledge, the sociology of knowledge discourse analysis, life-worldly ethnography, videography are but a few of these innovations in qualitative methods which constituted the turn towards the "interpretive paradigm" in the social sciences (Wilson 1970). ${ }^{2}$

As much as the communicative turn in the German sociology of knowledge was empirical, the need to relate to Habermas and Luhmann's communicative turn triggered some theoretical response. In this context, the notion of communicative construction got more and more widely used and entered into a number of studies. By the mid-nineties, various attempts to theorize communicative construction were made even by Luckmann himself. In the 2000s we lived to see the rise of 'communicative constructivism' as a movement in the German sociology of knowledge.

In this paper, I want to focus on this branch of the German sociology of knowledge which has been so much inspired by the "Social Construction of Reality". Leaving aside other approaches, communicative constructivism is probably the most innovative approach in German sociology of knowledge both, theoretically as well as empirically. In this paper, I want to focus only on the innovations in qualitative methodology which have been inspired by the "Social Construction of Reality". This theory first motivated studies in the sociology of language. Quite early, as we shall see in the following part, these studies also focused on interaction and communication. Gradually, methods have been developed which more and more related to what came to be called communicative action. In fact, as shall be argued in the next part, this empirical studies corresponding to the methods may be said to imply a program which, gradually, was labelled communicative constructivism. Recently, there have been some theoretical attempts to adumbrate what is meant communicative constructivism. The theory of communicative constructivism is elaborated elsewhere (Knoblauch, in print). In this paper, we can only sketch how it is related to the sociology of knowledge (as it has been framed by Social Constructivism as framed by Berger and Luckmann ${ }^{3}$ ) and its attempt to look for language as the major objectivation of social knowledge. The turn towards language in action, the empirical research on the context of communicative action and the impact of discourse, practice and actor-network theories led to reformulation of the theoretical programme in terms of communicative constructivism. In the final

${ }^{2}$ Henceforth I will refer to this as The Social Construction in short.

On the role of Berger and Luckmann's book in the rise of "Social Constructivism" cf. Knoblauch \& Wilke 2016 
outlook, we want to at least mention some aspects of the sociological background for this movement, i.e. communication society and refiguration.

\section{THE SOCIOLOGY OF KNOWLEDGE AND LANGUAGE}

The success of Berger and Luckmann's approach in Germany is very much indebted to the role of Weber's sociology in their book. Although they also stress the equivalent relevance of Durkheim, Weber's theory of action is quite decisive for their notion of knowledge. Action, to Weber, is essentially defined by meaning. Following Schutz who analysed the notion of meaning phenomenologically, we can take knowledge as socially mediated meaning (Knoblauch 2014). As a consequence and in accordance with the famous 'Thomas' theorem, action is dependent on and defined by knowledge. In reverse, the relevance of knowledge is due to the fact that it is or can be "realized" in social action.

The idea that (most) knowledge is socially mediated by others has been formulated in the sociology of knowledge by Schutz, who was the teacher of both, Berger and Luckmann. Therefore the subsequent studies that built on this theory have focused particularly on language. This is due to the assumption that language characterizes meanings, guiding both actions and social actions. Language is considered to be the best empirically accessible core of the social stock of knowledge, essentially defining the world view. In addition, language, as a historical sign system, is the most important resource of typifications, abstractions and generalization, by which mutual understanding is ensured for all practical purposes, for language contains the knowledge that is socially acknowledged within a community (Schutz 1962)

Following Schutz, also Berger and Luckmann regard language as the central mediator between individual consciousness and society. Language is the major "objectivation" by which externalized meaning becomes fixed, by which it is mediated and by which it is internalized. Berger and Luckmann's shift towards language was by no means idiosyncratic, for, at this time, most humanities and social science disciplines were going through a profound 'linguistic turn'. Encouraged by the works of Heidegger and Wittgenstein, by structuralism and speech act theory, language became more and more central, not only in the social and cultural sciences, but also within sociology. It is only during this period that a significant sociology of languages was developed - initially in the Anglo-Saxon world (Fishman, 1968). Habermas also turned to language, after Berger and Luckmann had declared language to be a central research area. Berger, for example, considered language to be the "first" social institution (Berger \& Berger, 1972) and Luckmann even contributed significantly to the establishment of the sociology of language (Luckmann 1975).

It is important to note that, in contrast to structuralist approaches, the phenomenology of Schutz, Berger and Luckmann maintained that typification and action is not determined by the meaning objectified in language or, as to that, in any structures. Nor did they share the relativism inducted by the famous Whorf-thesis. According to this theory, different languages exhibit almost unbridgeable differences with respect to basic temporal and spatial orientations, as argued by Whorf (1956) using the example of the Hopi language of North America. To phenomenology, there is also a prelinguistic ("prepredicative") meaning which constitutes much of the "life-world" of human actors. This life-world thesis got very much support by the then current anthropological knowledge on pre-linguistic experiences. One example was the famous investigation by Berlin and Kay (1969), which dealt with the basic words for colors in different cultures. Among other things, they were able to show that members of different cultures could distinguish colors for which they did not have categories. While this could be seen as evidence of what Husserl called "pre-predicative experiences" and what Schutz called "typification", Berlin and Kay also demonstrated that there are, so to speak, basic universal categories for colors (black and white), even if they are culturally and linguistically differentiated. Luckmann took such universals as an indication and proof of common structures within the lifeworld.

In contrast to Habermas, Luckmann's interest in language was not restricted to theory. He also contributed to the rapid development of empirical research into language. This was not limited to the sociological study of quantifiable correlations between linguistic and social characteristics, but extended to the increase in qualitative empirica analyses of speech. ${ }^{4}$ At the beginning of the 1970s, various methods emerged to study language use in its natural context, such as sociolinguistics (Labov), linguistic anthropology (Basso), ethnography of speech (Hymes, Gumperz), conversational analysis (Jefferson, Sacks, Schegloff) and interaction and context analysis (Goffman, Kendon).

\section{FROM LANGUAGE TO THE STUDY OF COMMUNICATION}

These empirical approaches, which spread worldwide in the 1970s and 1980s, have been characterized by a change of interest from language as an objective, abstract sign system to speech as action, and later to communication. In contrast to the speech act theory preferred by Habermas, which mainly analyzed language on the basis of examples invented by the analysts, and in contrast to Luhmann's purely theoretica approach to communication, these approaches took a decidedly empirical stance on language. Language was not to be examined simply as an abstract system, or a merely solitary performance, but as social action.

We have mentioned above that the spread of interest in language as social action went hand in hand with the rise of qualitative social research methods, such as various hermeneutic methods, conversational analysis, genre analysis, the ethnography of communication and the like. Many new qualitative methods have their origin in the study of language in use. One of the reasons for the important contribution of studying talk in action to the development of qualitative research is certainly the fact that it regarded spoken texts as a direct objectification of social action, as well as an expression of cultural interpretations or social structures. However, the successes of qualitative research, which have now become omnipresent in all social sciences, had a paradoxical effect on the study of language use that nurtured its success: In the course

${ }^{4}$ This approach was initiated by a conference held early in the 1960s, attended, amongst others, by Garfinkel, Goffman, Gumperz, Hymes, Luckmann and Sacks (Gumperz \& Hymes 1964). 
of the rise of qualitative methods, new methods increasingly distanced themselves from the concept of language that had dominated early studies on language use. Language had been considered as a phenomenon on its own (which could be correlated with socio-economic variables, for example), however attention was increasingly paid to the relevance of language as part of more encompassing processes which slowly came to be called communicative action.

The analysis of linguistic interactions remains, of course, an important subject of sociolinguistic research. Linguistics, for example, has begun to deal with conversational analysis from sociology, and linguistic pragmatics has increasingly turned to sociologically informed, interactional research methods and developed its own style of conversation analysis (Brinker et al. 2001, Deppermann 2000). This rather linguistic orientation is also characterized by interactional sociolinguistics, which was founded by John Gumperz and has been applied to various areas, such as gender (Günthner/ Kotthoff 1991).

While the linguistics of verbal interaction turned towards conversation analysis, sociology lost interest in natural conversation, as well as in language as a whole. Thus, at the turn of the millennium, we witnessed the "end of the linguistic turn" - at least in sociology and many other areas of the social sciences (Knoblauch 2000). Instead of a sociological study of language, qualitative methods turned towards meaning, knowledge and categories mediated by communication. Discourse analysis, based on Foucault, has been widely disseminated. Starting from the 'utterance', it regards linguistic phenomena as socially processed discourses. There is also an important branch of discourse analysis dedicated to the social constructivist approach (Keller et al. 2005).

As already mentioned, research initiated by Luckmann in the early 1980s was particularly influenced by ethnomethodological conversational analysis (Bergmann 1981). ${ }^{6}$ On the basis of recordings of 'natural' conversations, conversation analysts examined the order of turns at talk as produced by actors. One of the methodical innovations of this approach includes the analysis of communicative genres. With a naturalistic orientation to real-time interactions, this method searches for 'fixed' forms of communication, which it takes as expressions of routinized, socially relevant action problems. It thus directly links up to the sociological study of the 'institutionalization' of knowledge (Luckmann 1985). Inasmuch as genre analysis emphasizes the linguistic and para-linguistic 'internal' features of communicative genres, conversation analysis also links up to linguistics (Knoblauch \& Günthner 1995). In addition, it addresses sociological questions, for example, in the analysis of gossip (Bergmann 1987), conversions (Ulmer 1988) or arguments (Keppler 1994). Keppler has already dealt with the analysis of visual aspects of media communication from the perspectives of genre analysis (Keppler, 1985). As Ayaß' (1997) investigations of television sermons show, such analysis has also been applied to the mass media and their reception in action situations. With the spread of video technologies, amateur videos have increasingly ${ }^{5}$ The notion of communicative action has been in use before Habermas's “Theory of Communicative
Action” already by Schutz and Luckmann. Cf. Knoblauch 2013a).

${ }^{6}$ Luckmann (2013) explains this in his personal reminiscences. been analyzed, including internet videos (Traue \& Schünzel 2014).

The exploration of communicative processes in various social contexts is one of the central themes of the ethnography of communication. However, this approach has been increasingly neglected, so that today there are only a few works that explicitly and exclusively focus on the ethnography of communication. On the other hand, the question of the specific nature of linguistic and non-verbal communication in formal organizations has met with keen interest. Soeffner, Reichertz, Schröer and others have studied the communication processes involved in police work (Reichertz \& Schröer 1992). Luckmann, Bergmann and their working group (Luckmann \& Bergmann 1999) have dealt with the problem of whether and how different social organizations are characterized by the use of special communicative forms, patterns and genres, such as sexual counseling institutions, psychiatric institutions or ecology groups (Christmann 1997). The growing role of the non-verbal, visual aspects of communication have been accounted for by an increasing number of studies supported by video recordings. On these grounds, Tuma, Schnettler and Knoblauch (2013) have developed videography as an ethnographically oriented method of qualitative video analysis.

\section{THE IMPLICIT EMPIRICAL PROGRAM OF COMMUNICATIVE}

\section{CONSTRUCTIVISM}

The above-mentioned methods are only indicative of the range of empirical research within German Sociology of Knowledge inspired by The Social Construction. Since Luckmann, who later taught at the University of Constance, had been the center of a series of naturalistic studies on communicative processes, these studies have sometimes come to be referred to as the "Constance school". In addition to The Social Construction, such empirical studies have also drawn on Schutz, Garfinkel and Goffman. In the 1990s, "social-scientific hermeneutics" (Hitzler \& Honer 1997) and the "hermeneutic sociology of knowledge" emerged as a methodological frame for a new series of such studies (Reichertz et al., 1999, Schröer 1994 Soeffner 1997, which build primarily on Schutz's concept of the lifeworld.

As mentioned, in the Constance group of Luckmann, already in the 1980s the word 'communicative construction' gradually became a label for this naturalistic empirical research. Due to the strong inductive character of their methodology, however, the concept of "communicative construction" was hardly specified in theoretical terms. Yet, the empirical studies and the methods related to this label exhibit, indeed, some common traits that allow us to speak of an 'implicit program of communicative constructivism'.

The mostly qualitative and interpretive empirical analysis of social action in natural social situations on the basis of audio (and later audiovisual) records is paradigmatic for these studies. Until the 1980s, recordings were often made in laboratory-like situations. ${ }^{7}$ With the emergence of small audio cassette recorders, speech could be more

${ }^{7}$ This holds true for the large University of Konstanz project on a systematic take on the multimodality of face-to-face interaction, which was, however, never published in English. 
easily and increasingly better recorded in natural situations. With new technologies and the ensuing new possibilities of recording and reproducing, speech as a social activity could be studied empirically in ways which must be considered methodologically as highly valid. The question of how actions are performed by speech was no longer left to the imagination of the researchers, who invented speech acts at their desks while writing. Rather, speaking could now be easily recorded in its temporal sequence and in the context of social interactions, and thus became available as data for the most scrutinizing analyses. While data collection of linguistic interactions increasingly focused on these natural situations, methods were also developed to analyze the collected data in social scientific settings. For example, in conversation analysis as well as in hermeneutics, new forms of 'data sessions' and 'interpretation groups' emerged (Reichertz 2013).

Conversation analysis was initially interested in linguistic interactions, yet with the spread of video, it turned towards audiovisual recordings of interactions. Until the advent of video analysis, CA could not focus attention on visual aspects, thus excluding the body, objects related to it and spaces. Video analysis, on the other hand, was no longer restricted to simply linguistic actions and interactions, but was able to focus on what, in empirical studies, has increasingly come to be called 'communicative action'

While the empirical program of communicative constructivism is oriented towards the ethnomethodological notion of "processual reality" (Bergmann, 1981), it differs from ethnomethodology by also considering the institutional aspects of action. This stress on institutions is particularly evident in the concept of "communicative genres", which Luckmann (1985) compares to the "institutions" of communicative action. For Luckmann, institutions, technologies and social milieus form the "external structure" that is the context for interaction. The external structure includes the ethnographic context, social structures and other macrosocial aspects. This tendency to institutionalism is not shared by ethnomethodology, but derives from the social-constructivist background of this research.

Next to this naturalism, the empirical program of communicative constructivism also integrates subjectivity. The subjectivism of this research is due to its phenomenological roots (Eberle 2012). With regard to empirical research, phenomenology enters into lifeworld ethnography, but also into ethnophenomenological investigations of religious experiences and in videography, which also emphasizes the relevance of the subjective perspective, both to researchers as well as the researched (Knoblauch \& Schnettler 2015a).

The empirical research program of communicative constructivism is characterized by a strong level of inductionism. Instead of making assumptions about a specific society, the analysis of communicative genres, for example, should allow to reconstruct the 'communicative budget' applicable to different societies. This concept is so general that it can refer to the culture of the Mexican Chamula Indios as well as to Germans or Indians (Luckmann 1985). The method is inductive, because empirical evidence should indicate the particular structure of the 'communicative budget', its elements and their relevance. Although the specificity of society is left open, an overriding social-theoretical framework is assumed. However, this framework - apart from its con- certed parallels to grounded theory - has not been elaborated, and the same holds for the basic notion of communicative action.

If we look to other approaches for further theoretical support in order to elaborate this concept, we find reference to the theoretical role of 'social construction' in hermeneutics. Hermeneutics is not only used for the understanding of others, but also serves to "reconstruct the reconstruction (Soeffner 1997. The impact of The Social Construction is also recognized in the sociology of knowledge discourse analysis, which uses the term "discursive construction" to refer to Berger and Luckmann subject-oriented concept of action, rather than Foucault's idea of discourse, which considers subjectivity only as an effect of discourse (Keller 2013).

\section{MAJOR MODIFICATIONS FROM “SOCIAL” TO COMMUNICATIVE CONSTRUCTION}

Communicative constructivism, thus, appears to be an implicit program of these empirical studies. It supports the shift towards communication both empirically and methodically. As mentioned, by the end fo the 1990s the turn to communicative constructivism slowly became theorized (Knoblauch 1995; 2001; Luckmann 2013). As it will not be possible to give an outline of the whole theoretical model of communicative constructivism which has been elaborated elsewhere (Knoblauch 2017; Knoblauch in press), here we want to restrict ourselves to the major aspects by which communicative constructivism can be seen to differ from its predecessor, the 'social construction of reality' by Berger and Luckmann.

One should stress that the corresponding theoretical changes are not deduced from the empirical program. The empirical program, rather, substantiated the view that empirically, social action can only be studied as communicative action. If sociology depends, first and foremost, on understanding others then we need to presuppose something which allows understanding - and that is communication. And this kind of understanding is required for any actor on the social scene. As relevant as communication may be, understanding also presupposes some form of subjectivity. However, as opposed to classical Husserlian phenomenology, it is not the subject that is the exclusive reference point of analysis, of understanding or of action. The starting point of communicative construction is not the individual subject as distinct from other individuals, but subjects as related to other subjects, as well as to their objectivations. Relationality in this sense is one of the major assumptions of communicative constructivism. Against the background of the social constructionist rejection of the subject (as expressed most explicitly by Gergen 1985) we should emphasize, however, that this does not mean getting rid of the subject. Rather it means that the subject is not the sole center of the social; it is decentered by the relation. Yet, as we shall see, this relation cannot be understood without some formal notion of subjectivity. Formally presupposing subjectivity, subjects as entities are the result of communicative action, which contributes to various forms of the subjectivation.

The modified role of subjectivity is directly connected to a modification of the aspect of objectivity that has been addressed by 'new materialism'. In this vein, Latour 
(2005) criticizes the lack of consideration of materiality. Social constructivism, he complains, has neglected the role of objects, things and materials. As with his critique of objectivity, Latour's (2010). argument ignores a basic understanding of The Social Construction. In fact, Berger and Luckmann repeatedly stressed the materialism of social construction in their retrospective commentaries on The Social Construction. Berger, for example, emphasized that there is "a robust reality beyond our desires" (Berger 2011: 95) and Luckmann (1999) explicitly calls social construction materialistic and sketched in 1970 how 'non-humans' or things can be conceived of within the theory of the life-world Luckmann 1970). However, even though Berger and Luckmann expressly refer to Marx, it must be admitted that neither they nor their successors have explained what this materialism means in detail.

Yet if we look for a connection to materiality in The Social Construction, the crucial concept of 'objectivations' provides a helpful starting point. If we search for more detail, however, we realize that neither Berger nor Luckmann actively elaborated on the concept of objectivation. ${ }^{8}$ In their later writings they only focused on specific kinds of objectivation, particularly on linguistic objectifications. The reason for such focus is that they take language to determine the meaningful orientation of an action and since language itself represents a social institution, it is the medium by which subjects are being socialized. Luckmann in particular shifted his attention to linguistic action; the same holds for Habermas, whose "theory of communicative action" is based on speech act theory. Moreover, Foucault's discourse theory also takes the use of language (enoncé) as constitutive of discourse and, thence, to any understanding of social reality.

As relevant as language may be, however, it can hardly provide the basis for social theory for a simple reason: unless we assume that language is given by God, it presupposes others, their intercourse and, thence, sociality. If we want to explain sociality, we cannot, therefore, start with language. And if we want to explain the sociality of language, the notion of objectivation is quite apt - we take it to include non-linguistic objectivation. For Berger and Luckmann, objectivation includes physical "expressive motions" or objects (Berger \& Luckmann 1966 37). If we avoid restricting objectivations to simply linguistic sounds or characters, we can take them to include anything else carrying meaning: things, technologies, media and materialities. It is only by looking at physical and material processes and things that we can explain the socia construction of reality without having to presuppose language or discourse.

Next to the clarification of relationality, a theoretical elaboration of the concept of objectification and its materiality is, therefore, a second feature of communicative action and, as a consequence of the shift from 'social' to 'communicative construction'.

The third central modification of social construction is a consequence of the two prior arguments: If we move from subjectivity to relationality, we must also reformu-

8 "The very concept of objectivation implies that there are social facts as well, with a robust reality that can be discovered regardless of our wishes" (Berger 2011: 95); however, Berger distinguishes 'social facts' from 'physical facts', and his examples of physical facts are not really compelling, for example [...] that a particular massacre took place or by car was stolen" (ibid.). late the notion of action or, since relationality already implies at least two subjects, social action. And if we associate social action with objectivations, then the question arises as to how (at least two) subjects and objectification are connected with each other. While Berger and Luckmann conceive this connection as dialectical, it leaves open the question as to what constitutes sociality. Since we start from relationality, we will account for this connection by a triadic model of subjects and objectivation Moreover, we will assume that objectivation is what makes sense in the relation between subjects. This 'making sense by objectivation' we will call 'communicative', and since it requires subjects related to one another reciprocally, we will refer to it as com municative action. ${ }^{9}$

When we refer to an action between two subjects oriented towards objectivations as 'communicative', 'communicative' also seems to cover the everyday meaning of the word. Nevertheless, the extension of the term communicative beyond language to objectivations may sound strange to many ears, particularly as it substitutes notions such as action, social action, practice and communication. Therefore, proposing the concept of communicative action requires an explanation, legitimation and justification. We shall do so in the following chapter on social theory. This social-theoretical treatise goes into some detail, because it fulfills the task of reformulating the 'social' as 'communicative construction'. It is also extensive and detailed because it attempts to redefine the subject matter of the social sciences and the humanities. Sociality, here, is no longer understood as an addition to the subject, neither is the subject sacrificed in favor of a theory of sociality or culture. Sociality cannot be understood without subjectivity. That is why we focus on communicative action. It emphasizes the sociality of the objectivation processes, whilst maintaining the subjective standpoint in the concept of action.

\section{OUTLOOK: COMMUNICATION SOCIETY AND}

\section{THE REFIGURATION OF MODERNITY}

The changes in the sociology of knowledge indicated so far mostly relate to basic cat egories in social theory and methodology. As sociology always needs to reflect changes in society, the turn to communication and communicative constructivism also attempts to diagnose the contemporary transformation (Knoblauch 2016). In fact, the move from knowledge to communication mirrors the idea that the knowledge society of the last decade of the twentieth century have become communicative in a quite dramatic way. The dissemination of communication technology allows to transform anything into digital signs; as digital signs themselves become the medium not only for the storage of knowledge as information but also as the medium for action, we witness an excessive digital mediatisation (Knoblauch 2013): communication media allow to perform communication work in a way which increasingly includes industria production ("industry 4.0) as well as the new digitalized agriculture. Admittedly, this

${ }^{9}$ Reciprocity does not imply agreement, as the notion of and exclude conflicts, as one reviewer feared. Even fights depend on reciprocity, and conflict can be, as we see below, considered as one of the driving forces of contemporary society. 
form of digitization is not identical with the broad notion of communicative action which lies at the core of communicative constructivism. Rather, it is a cybernetic notion which is being implemented into software, materialized in infrastructures and, by increasingly self-generating knowledge about humans and nature and intra-acting autonomously, transforming knowledge society into a communication society.

This transformation is not seen as a linear process. As much as digital mediatization is characterized by the two opposing principles of centralization, monopolization and hierarchization of "communication power" on the one hand and the networking, democratization and heterarchization, recent societal development can be seen as resulting from the principles of modern bounded nation states on the one hand and transgressive, global- and glocalization. Refiguration means that these principles are not sequences in a historical development of or from modernity to late or postmodernity but rather resulting from the conflict which arise wherever these principles meet in more or less clear forms (as e.g. in the conflict between right wing populismus and cosmopolitanism or state nations or nationalism and transnationalism (Knoblauch/ Löw 2017). This conflict between different figurations is the driving force of the refiguration. It is one of the major theses of communicative constructivism that this refiguration crosses all scales of society and therefore requires the reformulation of the basic categories in social theory, such as social action. Communicative constructivism is, therefore, conceived as a movement which responds to this task in an empirically sensitive, yet theoretically constructive manner. ${ }^{10}$

FUNDING: This research received no external funding.

CONFLICTS OF INTEREST: The author declares no conflict of interest.

\section{REFERENCES}

Ayaß, Ruth. 1997. Das Wort zum Sonntag: Fallstudie einer kirchlichen Sendereihe. Stuttgart: Kohlhammer.

Berger, Peter L. \& Brigitte Berger. 1972, Sociology. New York: Basic Books.

Berger, Peter L. \& Thomas Luckmann. 1966. The social construction of reality: A treatise in the sociology of knowledge. New York: Pengiun Books.

Berger, Peter L. 2011. Adventures of an Accidental Sociologist: How to Explain the World without Becoming a Bore. Amherst: Prometheus Books.

Berger, Peter L. and Thomas Luckmann. 1963. "Sociology of Religion and Sociology of Knowledge.” Sociology and Social Research 47(4): 417-427.

Bergmann, Jörg. 1987. Klatsch. Zur Sozialform der diskreten Indiskretion. New York und Berlin: De Gruyter.

Bergmann, Jörg.1981. “Ethnomethodologische Konversationsanalyse.” Pp. 9-51 In P.

${ }^{10}$ The empirical study of as well as the analytical specification of how societies are refigured in spatially constitutes the task of a concerted research program (SFB) headed by Martina Löw and Hubert Knoblauch at the TU Berlin ("Re-Figuration of Space") and supported by the German Science Foundation (DFG)
Schröder and H. Steger (eds.), Dialogforschung. Jahrbuch des Instituts für deutsche Sprache. Düsseldorf: Schwann.

Brinker, K., Antos, G., Heinemann, W., and Sager, S. F. (eds.). 2001. Text- und Gesprächslinguistik/Linguistics of text and conversation: ein internationales Handbuch zeitgenössischer Forschung. Berlin: de Gruyter.

Christmann, Gabriela. 1997. Ökologische Moral. Zur kommunikativen Konstruktion und Rekonstruktion umweltschützerischer Moralvorstellungen. Wiesbaden: Deutscher Universitätsverlag.

Deppermann, Arnufllf. 2000. "Ethnographische Gesprächsanalyse: Zu Nutzen und Notwendigkeitvon Ethnographie für die Konversationsanalyse.” Gesprächsforschung - Online-Zeitschrift zur verbalen Interaktion 1: 96-124.

Eberle, Thomas. 2012. "Phenomenology and Sociology: Divergent Interpretations of a Complex Relationship.” Pp. 151-67 in Interaction and Everyday Life: Phenomenological and Ethnomethodological Essays in Honor of George Psathas, edited by G. Psathas, H. Nasu, and F. Ch. Waksler. Lanham: Lexington Books.

Fishman, Joshua A. 1968. Readings in the Sociology of Language. Den Haag.

Gumperz, John J. and Dell H. Hymes, (eds.). 1964. The Ethnography of Communication. Washington: American Anthropological Association.

Günthern, Susanne and Hubert Knoblauch. 1995. "Culturally patterned speaking practices - the analysis of communicative genres.” Pragmatics 5: 1-32.

Günthner, Susanne and Helga Kotthoff. 1991. Von fremden Stimmen. Weibliches und männliches Sprechen im Kulturvergleich. Frankfurt am Main: Suhrkamp.

Hacking, Ian. 1999. The social construction of what? Cambridge, MA: Harvard University Press.

Hitzler, Ronald and Anne Honer. 1997. "Hermeneutik in der deutschsprachigen Soziologie heute.” Pp. 7-27 in A. Honer \& H. Ronald (eds.), Sozialwissenschaftliche Hermeneutik. Opladen: Leske + Budrich.

Kay, Peter and Berlin, Brent. 1969. Basic color terms: Their universality and evolution. Berkeley: Berkeley University Press.

Keller, Reiner, Hirseland, A., Schneider, Werner and Viehöver, Wolfgang. eds. 2005. Die diskursive Konstruktion von Wirklichkeit. Konstanz: UVK.

Keppler, Angela. 1985. Information und Präsentation. Zur politischen Berichterstattung im Fernsehen. Tübingen: Niemeyer.

Keppler, Angela. 1994. Tischgespräche. Über Formen kommunikativer Vergemeinschaftung am Beispiel der Konversation in Familien. Frankfurt am Main: Suhrkamp.

Knoblauch, Hubert. 2013. "Qualitative methods at the crossroads: Recent developments in interpretive social research.” Forum Qualitative Sozialforschung 14: 3.

Knoblauch, Hubert (in print). The Communicative Construction of Reality. London: Routledge.

Knoblauch, Hubert and Martina Löw. 2017. “On the Spatial Re-Figuration of the Social World.” Sociologica 2/2017. doi: 10.2383/88197

Knoblauch, Hubert and Schnettler Bernt. 2015. "Video and Vision: Videography of a Marian Apparition.” Journal of Contemporary Ethnography 44(5): 636-656.

Knoblauch, Hubert and Bernt Schnettler. 2012. "Videography: Analysing video data 
as “focused” ethnographic and hermeneutical exercise." Qualitative Research 12 334-356.

Knoblauch, Hubert and Rene Wilke. 2016. “The Common Denominator: The Reception and Impact of Berger and Luckmann's The Social Construction of Reality.” Human Studies 39(1): 51-69.

Knoblauch, Hubert. 1995. Kommunikationskultur: die kommunikative Konstruktion kultureller Kontexte. Berlin, New York: De Gruyter.

Knoblauch, Hubert. 2000. „Das Ende der linguistischen Wende. Sprache und empirische Wissenssoziologie." Soziologie 2: 46-58.

Knoblauch, Hubert. 2001. "Communication, contexts and culture. A communicative constructivist approach to intercultural communication.” Pp. 3-33 in di Luzio, A., Günthner, S. \& F. Orletti (eds.). Culture in communication. Analyses of intercultural situations. Amsterdam \& Philadelphia: John Benjamins.

Knoblauch, Hubert. 2013a. "Alfred Schutz' Theory of Communicative Action." Human Studies 36(3): 323-337.

Knoblauch, Hubert. 2014. Wissenssoziologie. Kosntanz: UVK.

Knoblauch, Hubert. 2016. "Communicative Constructivism and the Communication Society.” Pp. 185-200 in Elzbieta Halas (Hg.). Life-World, Intersubjectivity and Culture. Contemporary Dilemmas. Frankfurt/ Main u.a.

Knoblauch, Hubert and Rene Wilke. 2016. "The Common Denominator: The Reception and Impact of Berger and Luckmann's The Social Construction of Reality.” Human Studies 39(1): 51-69.

Latour, Bruno. 2005. Reassembling the social: An introduction to Actor-Network-Theory. Oxford: Oxford University Press.

Latour, Bruno. 2010. “On the cult of the factish Gods.” Pp. 1-67 in B. Latour, On the modern cult of the factish Gods. Durham \& London: Duke University Press.

Luckmann, Thomas. 1970. "On the Boundaries of the Social World.” in M. Natanson (ed.), Phenomenology and Social Reality. Essays in Memory of Alfred Schutz. The Hague.

Luckmann, Thomas. 1975. The sociology of language. Indianapolis: Bobbs Merrill.

Luckmann, Thomas. 1985. “The analysis of communicative genres.” Pp. 48-61 in B. F. Nell, R. Singh \& W. M. Venter (ed.), Focus on quality. Selected proceedings of a conference on qualitative research methodology in the social sciences. Durban: Institute for Social and Economic Research.

Luckmann, Thomas. 1999. “Wirklichkeiten, Individuelle Konstitution und gesellschaftliche Konstruktion.” Pp. 17-28 in R. Hitzler, J. Reichertz \& N. Schröer (eds.), Hermeneutische Wissenssoziologie: Standpunkte zur Theorie der Interpretation. Konstanz: UVK.

Luckmann, Thomas. 2013. "The communicative construction of reality and sequential analysis. A personal reminiscence." Qualitative Sociology Review IX: 40-46.

Reichertz, Jo and Schröer, Norbert (eds.). 1992. Polizei vor Ort. Studien zur empirischen Polizeiforschung. Stuttgart: Enke.

Reichertz, Jo, Hitzler, Ronald and Schröer, Nrobert (eds.). 1999. Hermeneutische Wissenssoziologie. Standpunkte zur Theorie der Interpretation. Konstanz: UVK.
Reichertz, Jo. 2013. Gemeinsam interpretieren: die Gruppeninterpretation als kommunikativer Prozess. Wiesbaden: Springer VS.

Schröer, Norbert. (ed.) 1994. Interpretative Sozialforschung: auf dem Wege zu einer hermeneutischen Wissenssoziologie. Opladen: Westdeutscher Verlag.

Schutz, Alfred. 1962. "Symbol, reality and society.” Pp. 287-356 in A. Schutz (ed.), Collected papers I- The Problem of Social Reality. The Hague: Nijhoff.

Schutz, Alfred. 1967. The phenomenology of the Social World. Evanston: Northwestern University Press.

Soeffner, Hand-Georg. 1991. "Verstehende Soziologie und sozialwissenschaftliche Hermeneutik - Die Rekonstruktion der gesellschaftlichen Konstruktion der Wirklichkeit.” Berliner Journal für Soziologie 1(2): 263-269.

Soeffner, Hans-Georg. 1997. The Order of Rituals. The Interpretation of Everyday Life. New Brunswick, London: Transaction.

Traue, Boris and Anja Schünzel. 2014. "Visueller Aktivismus und affektive Öffentlichkeiten: Die Inszenierung von Körperwissen in "Pro Ana"- und "Fat Acceptance”-Blogs.” Österreichische Zeitschrift für Soziologie 39 (Special Issue 1): 121-142. http://doi.org/10.1007/s11614-014-0134-6

Tuma, Rene, Bernt Schnettler, and Hubert Knoblauch. 2013. Videographie: Einführung in die interpretative Videoanalyse sozialer Situationen. Wiesbaden: Springer VS.

Ulmer, Bernd. 1988. “Konversionserzählungen als rekonstruktive Gattung.” Zeitschrift für Soziologie 17(1): 19-33.

Whorf, Benjamin Lee. 1956. Language, thought, and reality: Selected writings of Benjamin Lee Whorf. Cambridge \& New York: MIT Press.

Wilson, Thomas P. 1970. "Conceptions of Interaction and Forms of Sociological Explanation.” American Sociological Review 35(4): 697-710.

\section{BIOGRAPHICAL NOTE}

Hubert Knoblauch is professor in sociology at the Technical University of Berlin, Germany.

OPEN ACCESS: This article is distributed under the terms of the Creative Commons Attribution Noncommercial License (CC BY-NC 4.0) which permits any noncommercial use, and reproduction in any medium, provided the original author(s) and source are credited. 
